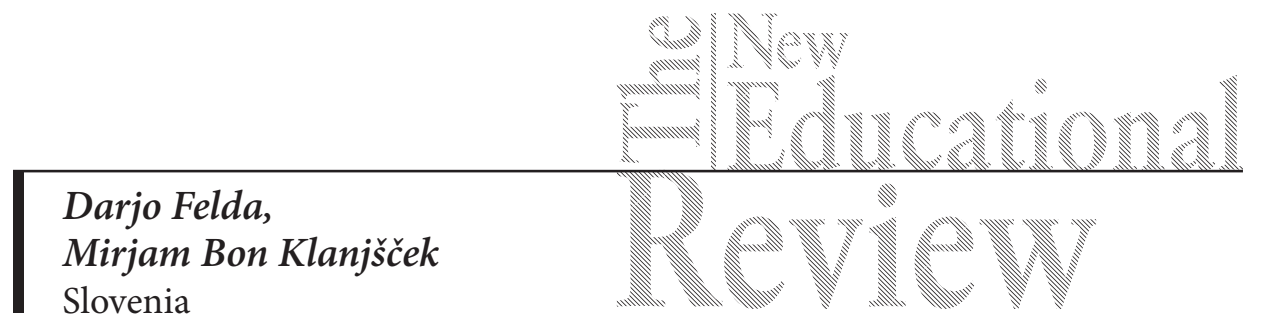

\title{
Teaching Statistics in the Background of Teaching Mathematics
}

DOI: 10.15804/tner.2017.48.2.05

\begin{abstract}
In math classes solving statistical tasks by using procedures which the student learned by heart is usually used. The authors, thus encouraged learning and teaching statistics on the basis of realistic problems and problem situations, so that the student gets to know statistical concepts within the experience of resolving a real-life problem situation. With this approach to learning and teaching statistics, students acquired a better knowledge and were able to grasp, interpret and make critical evaluations of the statistical information, which was confirmed by the experiment that involved 269 first-grade high school students.
\end{abstract}

Keywords: teaching statistics, mathematics, problem-solving approach, statistical reasoning.

\section{Introduction}

Statistics lessons are mostly part of mathematics lessons, although the opinions of experts in the field of statistical education differ in whether the inclusion of statistics lessons in mathematics lessons is the best solution, since some of them mention large differences between mathematics and statistics, especially between statistical and mathematical thinking. Others believe that such differences would not exist if we emphasized logical thinking instead of problem-solving with learned algorithms (Watson, 2006; Biehler, 2008; Porkess, 2011). 
In mathematics lessons in high schools in Slovenia, within which statistics is taught, insufficient attention is paid to statistical literacy, although in the context of statistics, there is an emphasis on the link between statistics and the real world, namely the use of statistics in various problem situations. In addition, procedural solving and reinforcing statistical tasks with the use of procedures which the student learned by heart, often prove to be unsuccessful, since the student does not understand statistical concepts and is neither aware of the sense and effectiveness of solving processes nor able to assess the accuracy or inaccuracy of the solution.

The authors were thus looking for such an approach to learning and teaching statistics which was based on realistic statistical problems and appropriate problem situations. The learning and teaching approach emphasises the problem-solving approach, where the student encounters a statistical term or a concept and gets to know it either in a problem situation or directly at its resolution, whereby he/she is able to use his/her prior knowledge and experience in acquiring new skills and learning strategies.

\section{Purpose and objectives of the research}

The purpose of the research was to use such an approach to learning and teaching with problem situations and realistic statistical problems included, arising from everyday life, to develop the application of statistics in real-life situations and thus improve statistical literacy. The authors were interested in finding how the novelties defined by that approach to learning and teaching affected statistics lessons in high schools or improved the knowledge of statistics and increased the level of statistical literacy. More precisely, the authors checked whether the impact was linked to the mark in mathematics.

\section{Empirical part}

\section{Basic research method and research approach}

In the research, a descriptive and causal-experimental method in the pedagogical research was used. In the context of the research, the pedagogical non-probability experiment with intentional registering of the experimental factor in the research situation was used.

In order to get the best possible idea of the experiment, the data were collected quantitatively, namely with two written examinations in statistics, one at the beginning of the experiment, and the other at the end. 
In cooperation with teachers from the experimental group, we planned the preparations for learning units and prepared materials for the preparation of an independent statistical task, including instructions for computer processing of the data. In addition to the textbook for the first grade of high school, including statistics contents, teachers and students used materials including statistical problems from the students' real lives.

The mathematics teachers who were selected for the control group used the same textbook as the experimental group. They were informed that we were going to monitor the statistics lessons in the research, however, they did not know that in the second group we were going to introduce a new approach to learning and teaching statistics, and monitor the development of statistical literacy. We had not specifically prepared those teachers to participate in this experiment, together with them we only planned the dates of examinations and checked the number of hours of statistics lessons, as well as expected that they would operate in the selected section as they normally did when they performed their work.

\section{Experiment model}

A single-factor model of a non-probability experiment with high-school departments as control groups was designed, with two modalities of an experimental factor:

- teaching statistics according to the usual syllabus with a conventional approach, used by teachers in mathematics classes;

- teaching statistics according to the usual syllabus by incorporating problem situations and realistic statistical problems arising from everyday life.

Comparative groups from existing first-grade departments in various high schools were established. The group of students in which the experiment was introduced, which incorporated the completed model of statistics teaching including problem situations and realistic problems from everyday life and active participation of students, was called the experimental group (EG). The group of students which was part of the traditional, namely the transmission model of statistics lessons, was called the control group (CG). Due to internal validity, the most relevant factors, namely the socio-economic status of each individual student's family, taking into account the level of education of the parent or guardian who had a higher education degree, and mathematics marks were initially monitored. 


\section{Experiment sample}

The research took place at high schools in Slovenia with equal opportunities for work. 269 first-grade students participated in this experiment. The experimental group included 134 students and the control group included 135 students.

\section{Socio-economic status of the student's family}

Firstly, it was checked whether the experimental group and the control group were tied regarding the socio-economic status of the family of an individual student. For this purpose, the students were divided into six groups based on the highest degree of education of their parents, as shown in Table 1.

Table 1. Frequency divisions of students according to the socio-economic status of their families

\begin{tabular}{lcccc}
\hline & Group & $\begin{array}{c}\text { Frequen- } \\
\text { cy }\end{array}$ & $\begin{array}{c}\text { Frequency } \\
\text { (in \%) }\end{array}$ \\
\hline Primary school or unfinished primary school & EG & 2 & 1.5 \\
\cline { 2 - 4 } & CG & 1 & 0.7 \\
\hline Lower or upper-secondary vocational education & EG & 14 & 10.5 \\
\cline { 2 - 4 } & CG & 9 & 6.7 \\
\hline Upper-secondary technical education or general education & EG & 33 & 24.6 \\
\cline { 2 - 4 } & CG & 35 & 25.9 \\
\hline Vocational college or post-secondary education & EG & 36 & 26.9 \\
\cline { 2 - 4 } & CG & 50 & 37.0 \\
\hline Higher professional or academic education & EG & 45 & 33.6 \\
\cline { 2 - 4 } & CG & 35 & 25.9 \\
\hline Master's degree or doctorate & EG & 4 & 3.0 \\
\hline
\end{tabular}

Based on Table 1, it was concluded that the experimental and control groups were not significantly different based on the socio-economic status of the families of each individual student. With a $\chi^{2}$ test it was confirmed that there were no statistically significant differences between the groups ( $\mathrm{p}=0.323$ ).

\section{Mathematics marks prior to the beginning of the experiment}

It was also tested whether there were any statistically significant differences between the experimental and control groups based on the students' success in mathematics. The frequency division of the students' mathematics markes from the experimental and control groups is presented in Table 2. The students' mathe- 
matics marks in the final grade of primary school were taken into account, ranging from sufficient (2) to excellent (5) marks.

Table 2. Frequency division of marks in mathematics in the EG and CG

\begin{tabular}{llll}
\hline \multicolumn{1}{r}{ Marks } & Group & Frequency & $\begin{array}{c}\text { Frequency } \\
\text { (in \%) }\end{array}$ \\
\hline $\begin{array}{l}\text { Sufficient } \\
(2)\end{array}$ & EG & 9 & 6.7 \\
\cline { 2 - 4 } $\begin{array}{l}\text { Good } \\
(3)\end{array}$ & EG & 4 & 3.0 \\
\cline { 2 - 4 } $\begin{array}{l}\text { Very good } \\
(4)\end{array}$ & EG & 24 & 17.9 \\
\hline EG & CG & 53 & 23.0 \\
\hline $\begin{array}{l}\text { Excellent } \\
(5)\end{array}$ & EG & 45 & 48.0 \\
\hline
\end{tabular}

With a $\chi 2$ test it was confirmed that there were no statistically significant differences between the experimental and control groups based on marks in mathematics $(\mathrm{p}=0.400)$.

It was thus discovered that the experimental and control groups were completely equalized given the socio-economic status of each individual student and according to the mathematics marks in the final grade of primary school.

\section{Course of the research and data collection}

At the beginning, initial knowledge assessment was performed, and final assessment at the end. The tasks were formed in accordance to the applicable syllabus for first-grade high school mathematics lessons, which includes the statistics content, and in accordance with the objectives, which are defined in the syllabus. In the preparation of the two assessments, the examples from the international PISA (PISA, 2012) and TIMSS (Japelj Pavešić, 2012) studies were followed, which included the tasks from the data processing area. Both the initial and final knowledge assessments contained six tasks taking into account Gagnés classification of learning outcomes, namely with two tasks each from each taxonomic rank:

I - basic knowledge of statistical concepts;

II - statistical task solving, with which the procedural knowledge was checked;

III - statistical problem solving.

Table 3 shows the composition of individual tests given the statistical content and number of possible points for each task. 
Table 3. Statistical content and number of points in the initial and final knowledge assessment

\begin{tabular}{cccll}
\hline \begin{tabular}{c} 
Suq. No. $\begin{array}{c}\text { of the } \\
\text { task }\end{array}$ \\
\cline { 2 - 5 }
\end{tabular} & $\begin{array}{c}\text { Initial } \\
\text { assessment }\end{array}$ & $\begin{array}{c}\text { Final } \\
\text { assessment }\end{array}$ & \multicolumn{1}{c}{ Initial assessment } & \multicolumn{1}{c}{ Final assessment } \\
\hline 1. & 2 & 3 & $\begin{array}{l}\text { Knowledge of the ways to } \\
\text { display data (circular and } \\
\text { with columns) }\end{array}$ & $\begin{array}{l}\text { Knowledge of statisti- } \\
\text { cal terms (mean, mode, } \\
\text { median) }\end{array}$ \\
\hline 2. & 3 & 6 & $\begin{array}{l}\text { Knowledge of the statis- } \\
\text { tical terms (mean, mode, } \\
\text { median) }\end{array}$ & $\begin{array}{l}\text { Knowledge of statistical } \\
\text { terms (average, average ab- } \\
\text { solute deviation, standard } \\
\text { deviation) }\end{array}$ \\
\hline 3. & 5 & 6 & $\begin{array}{l}\text { Application of statistical } \\
\text { terms (data concentration) }\end{array}$ & $\begin{array}{l}\text { Application of statistical } \\
\text { terms (data concentration, } \\
\text { columns) }\end{array}$ \\
\hline 4. & 4 & 4 & $\begin{array}{l}\text { Application of statistical } \\
\text { terms (data concentration, } \\
\text { displays) }\end{array}$ & $\begin{array}{l}\text { Application of statistical } \\
\text { terms (range, interquartile } \\
\text { range, box plot) }\end{array}$ \\
\hline 5. & 6 & 4 & Statistical problem & Statistical problem \\
\hline 6. & 4 & 6 & Statistical problem & Statistical problem \\
\hline Total: & 24 & 29 & & \\
\hline
\end{tabular}

The students from both groups took both the initial and the final knowledge assessments under the same conditions. All the tasks which were included in the knowledge test were open-ended. Each assessment lasted 60 minutes.

We used Spearman's rank correlation coefficient with both groups in order to examine the correlation between the achievements in the initial knowledge assessment, the achievements in the final knowledge assessment and the success in mathematics for each of these variables.

With the use of descriptive analysis, we also checked the distribution of the scored points and the adequate dispersion in both groups in the initial and final knowledge assessments, and analyzed the achievements of the students from both groups in the initial and final knowledge assessments in relation to the students' marks in mathematics. 


\section{Results and interpretation}

\section{Correlation between the achievements in assessments and marks in mathematics}

In the research, the correlation between the achievements in the initial knowledge assessment, the achievements in the final knowledge assessment and the success in mathematics for each pair of the aforementioned statistical elements both in the experimental and control groups were studied.

Spearman's rank correlation coefficient and an appropriate level of statistical significance for the students from the experimental group are shown in Table 4 for the correlation between each two statistical elements: achievement in the initial assessment, achievement in the final assessment and marks in mathematics. The data for the students from the control group arepresented in Table 5.

Table 4. Correlation between the achievements of the initial assessment, the achievements in the final assessment and the marks in mathematics in the EG

\begin{tabular}{llccc}
\hline & & $\begin{array}{c}\text { Initial } \\
\text { assessment }\end{array}$ & $\begin{array}{c}\text { Final } \\
\text { assessment }\end{array}$ & $\begin{array}{c}\text { Mathematics } \\
\text { mark }\end{array}$ \\
\hline Initial assess- & Correlation coefficient & 1.000 & 0.456 & 0.464 \\
ment & Level of statistical significance & & 0.000 & 0.000 \\
\hline Final assess- & Correlation coefficient & 0.456 & 1.000 & 0.602 \\
ment & Level of statistical significance & 0.000 & & 0.000 \\
\hline Mathematics & Correlation coefficient & 0.464 & 0.602 & 1.000 \\
mark & Level of statistical significance & 0.000 & 0.000 & \\
\hline
\end{tabular}

Table 5. Correlation between the achievements of the initial assessment, the achievements in the final assessment and the marks in mathematics in the CG

\begin{tabular}{llccc}
\hline & & $\begin{array}{c}\text { Initial } \\
\text { assessment }\end{array}$ & $\begin{array}{c}\text { Final } \\
\text { assessment }\end{array}$ & $\begin{array}{c}\text { Mathematics } \\
\text { mark }\end{array}$ \\
\hline Initial assess- & Correlation coefficient & 1.000 & 0.474 & 0.413 \\
ment & Level of statistical significance & & 0.000 & 0.000 \\
\hline Final assess- & Correlation coefficient & 0.474 & 1.000 & 0.612 \\
ment & Level of statistical significance & 0.000 & & 0.000 \\
\hline Mathematics & Correlation coefficient & 0.413 & 0.612 & 1.000 \\
mark & Level of statistical significance & 0.000 & 0.000 & \\
\hline
\end{tabular}

Spearman's rank correlation coefficients showed a positive correlation for each pair of the aforementioned statistical elements both in the experimental and control groups. In addition, all the correlations are statistically significant since 
the level of statistical significance in all the cases is the same, i.e., 0.000 (Tables 4 and 5).

Both groups showed the biggest correlation between the marks in mathematics and the achievements in the final assessment. In the experimental group, the coefficient amounted to 0.602 , and in the control group it amounted to 0.612 , which in both groups shows a moderate correlation between the marks inmathematics and achievements in the final assessment. This means that the students with higher marks in mathematics obtained better results in the final assessment regardless of the approaches to teaching and learning statistics.

The correlation coefficients in both groups show a bad correlation between the remaining variable pairs (Tables 4 and 5).

\section{Comparison of achievements in the initial and final assessments}

\section{Comparison of the achievements of the students in the experimental group in the} initial and final assessments based on their marks in mathematics

Table 6 presents the basic statistical parameters of the achievements of the students in the experimental group in the initial and final knowledge assessments, namely the marks in mathematics, the number of students, the arithmetic mean, standard deviation and the minimum and maximum achievement.

Table 6. The achievements of the EG students in the initial and final knowledge assessments based on their marks in mathematics

\begin{tabular}{lccccccc}
\hline & $\begin{array}{c}\text { Maths } \\
\text { mark }\end{array}$ & $\begin{array}{c}\text { No. of } \\
\text { students }\end{array}$ & $\begin{array}{c}\text { Arith. } \\
\text { mean }\end{array}$ & $\begin{array}{c}\text { Arith. mean } \\
\text { (in \%) }\end{array}$ & $\begin{array}{c}\text { Stand. } \\
\text { deviation }\end{array}$ & Min. & Max. \\
\hline $\begin{array}{l}\text { Initial assess- } \\
\text { ment }\end{array}$ & 2 & 9 & 11.00 & 45.8 & 4.92 & 3.00 & 20.00 \\
\cline { 2 - 8 } & 3 & 24 & 11.79 & 49.1 & 4.03 & 4.00 & 22.00 \\
\cline { 2 - 8 } & 4 & 53 & 13.21 & 55.0 & 3.47 & 4.00 & 20.00 \\
\cline { 2 - 8 } & 5 & 48 & 16.29 & 67.9 & 3.23 & 10.00 & 23.00 \\
\cline { 2 - 8 } & Total & 134 & 13.91 & 58.0 & 4.03 & 3.00 & 23.00 \\
\hline \multirow{2}{*}{$\begin{array}{l}\text { Final assess- } \\
\text { ment }\end{array}$} & 2 & 9 & 9.89 & 34.1 & 7.27 & 4.00 & 23.00 \\
\cline { 2 - 8 } & 3 & 24 & 15.79 & 54.5 & 6.04 & 2.00 & 27.00 \\
\cline { 2 - 8 } & 5 & 48 & 23.79 & 82.0 & 2.73 & 17.00 & 28.00 \\
\cline { 2 - 8 } & Total & 134 & 19.07 & 65.8 & 6.60 & 2.00 & 28.00 \\
\hline
\end{tabular}

A student from the experimental group with a sufficient (2) mark in mathematics obtained, on average, a lower result in the final assessment than in the initial 
assessment, i.e., in the initial assessment they scored on average $45.8 \%$ of the total score, and in the final assessment on average only $34.1 \%$ of the total score. This is not surprising since the students with low marks in mathematics usually had problems even with understanding the basic mathematical concepts and often learned mathematical concepts and formulas by heart and were, therefore, unable in most cases to use them. Thus, we can also conclude that for those students a real understanding of the basic concepts of statistical terms was poor.

The students with good (3) and very good (4) marks obtained, on average, a better result in the initial assessment, and the students with the excellent (5) mark in the final assessment greatly improved their average result.

\section{Comparison of the achievements of the students in the experimental group} in the initial and final assessments based on their marks in mathematics

Table 7 presents the basic statistical parameters of the achievements of the students in the control group in the initial and final knowledge assessments, i.e., the marks in mathematics, number of students, the arithmetic mean, standard deviation and minimum and maximum achievement.

Table 7. The achievements of CG students in the initial and final knowledge assessments based on their marks in mathematics

\begin{tabular}{lccccccc}
\hline & $\begin{array}{c}\text { Maths } \\
\text { mark }\end{array}$ & $\begin{array}{c}\text { No. of } \\
\text { students }\end{array}$ & $\begin{array}{c}\text { Arith. } \\
\text { mean }\end{array}$ & $\begin{array}{c}\text { Arith. mean } \\
\text { (in \%) }\end{array}$ & $\begin{array}{c}\text { Stand. } \\
\text { deviation }\end{array}$ & Min. & Max. \\
\hline $\begin{array}{l}\text { Initial assess- } \\
\text { ment }\end{array}$ & 2 & 4 & 10.00 & 41.7 & 1.41 & 8.00 & 11.00 \\
\cline { 2 - 8 } & 3 & 31 & 11.45 & 47.7 & 3.32 & 6.00 & 17.00 \\
\cline { 2 - 8 } & 4 & 55 & 14.38 & 59.9 & 3.92 & 6.00 & 22.00 \\
\cline { 2 - 8 } & 5 & 45 & 15.60 & 65.0 & 3.85 & 4.00 & 24.00 \\
\cline { 2 - 8 } & Total & 135 & 13.96 & 58.3 & 4.06 & 4.00 & 24.00 \\
\hline \multirow{2}{*}{ Final assessment } & 2 & 4 & 10.25 & 35.3 & 5.12 & 5.00 & 17.00 \\
\cline { 2 - 8 } & 3 & 31 & 11.32 & 39.0 & 3.76 & 3.00 & 22.00 \\
\cline { 2 - 8 } & 4 & 55 & 15.09 & 52.0 & 4.27 & 7.00 & 27.00 \\
\cline { 2 - 8 } & 5 & 45 & 19.40 & 66.9 & 4.47 & 7.00 & 29.00 \\
\cline { 2 - 8 } & Total & 135 & 15.52 & 53.5 & 5.26 & 3.00 & 29.00 \\
\hline
\end{tabular}

It is evident from Table 7 that only the control group students with the excellent (5) mark in mathematics in the final assessment obtained, on average, a slightly higher score in comparison to their average achievement in the initial assessment, whereas the students with sufficient (2), good (3) and very good (4) marks in mathematics did not show progress in the final assessment compared to the ini- 
tial assessment, since they, on average, obtained a worse result than in the initial assessment.

We may conclude that in the control group with the transmission model of statistics lessons, only the students with the excellent (5) mark in mathematics showed some progress in their knowledge of statistics, whereas the remaining students did not show progress in their knowledge of statistics.

\section{Conclusions}

Within the context of the research, the traditional model of teaching statistics in Slovenian high schools was studied and deficiencies, particularly in terms of an insufficient contribution to the desired level of statistical literacy, were noted. For this reason, an appropriate approach to learning and teaching statistics was established, with the intention to correct these deficiencies. In the preparation of this approach, the results of the studies in which the authors emphasised the importance of dealing with basic statistical problems and critical interpretation of the results were considered (Graham, 2006; Stuart, 2005). Despite the fact that the statistics were being discussed within the framework of a mathematics syllabus, the differences in mathematics and statistics, especially the differences between mathematical and statistical thinking were taken into consideration, and logical thinking is more advantageous than dealing with algorithms only learnt by heart (Watson, 2006; Porkess, 2011).

With our approach to teaching and learning statistics, a better and more permanent knowledge was acquired, since the students in the experimental group were more able to grasp, interpret and make critical evaluations of the statistical information and achieve a higher level of statistical literacy, as was also found by some other authors of research worldwide (Best, 2004; Chick \& Pierce, 2013). Only the students with the lowest marks in mathematics did not achieve the desired level of statistical literacy despite the problem approach of teaching statistics. On the other hand, the students who in the context of the class solved and reinforced statistical tasks only by using procedures, mostly did not show progress in the construction of statistical literacy. In this group, only the students with the highest marks in mathematics made some progress in the knowledge of statistics.

Certainly, teachers must also be able to understand statistics in the right sense in order to be able to transfer it to their students in such a way that it would affect their development and ability to use a statistical method of thinking, thus we need to encourage teachers' statistical literacy and tstatistical thinking. Teacher capacity 
is a key dimension in realizing the essential goals for developing students' statistical literacy, reasoning and thinking in practical teaching (Zhang \& Stephens, 2016). Students should be included in the learning process and teachers should encourage critical thinking that represents an important task of mathematics education (Maričić \& Špijunović, 2015) as well as statistics education.

\section{References}

Best, J. (2004). More Damned Lies and Statistics: How Numbers Confuse Public Issues. California: University of California Press.

Biehler, R. (2008). From statistical literacy to fundamental ideas in mathematics: How can we bridge the tension in order to support teachers of statistics. In: C. Batanero, G. Burrill, C. Reading \& A. Rossman (Eds.), Joint ICMI/IASE Study: Teaching Statistics in School Mathematics, Challenges for Teaching and Teacher Education. Proceedings of the ICMI Study 18 and 2008 IASE Round Table Conference. Retrieved 1/12/2015, from http://iase-web.org/documents/papers/rt2008/Panel1_Biehler.pdf.

Chick, H.L., \& Pierce, R. (2013). The statistical literacy needed to interpret school assessment data. Mathematics Teacher Education and Development, 15 (2), 5-26. Retrieved 11/02/2016, from http://files.eric.ed.gov/fulltext/EJ1018712.pdf.

Graham, A. (2006). Developing thinking in statistics. London: Paul Chapman Publishing. Retrieved 31/01/2015, from http://ilam.fundacionilam.org/ILAMDOC/Developing_Thinking_Statistics.pdf.

Japelj Pavešić, B. (Ed.) (2012). Matematične naloge raziskave TIMSS [TIMSS Mathematics Items]. Ljubljana: Pedagoški inštitut.

Maričić, S., \& Špijunović, K. (2015). Developing Critical Thinking in Elementary Mathematics Education through a Suitable Selection of Content and Overall Student Performance. Procedia - Social and Behavioral Sciences, 180, 653-659.

PISA (2012). Mathematics Literacy Items (2006 and 2012). Retrieved 3/08/2015, from https://nces.ed.gov/surveys/pisa/pdf/items_math2012.pdf.

Porkess, R. (2011). The Future of Statistics in our Schools and Colleges. The Royal Statistical Society and the Actuarial Profession, London. Retrieved 3/02/2016, from http:// www.bing.com/search?q=The+Future+of+Statistics+in+our+School+and+Colleges\&s$\mathrm{rc}=$ IE-SearchBox\&FORM=IENTTR\&conversationid.

Stuart, M. (2005). Mathematical Thinking versus Statistical Thinking; Redressing The Balance in Statistical Teaching. Retrieved 20/11/2012, from https://www.scss.tcd.ie/ disciplines/statistics/tech-reports/0507.pdf.

Watson, J.M. (2006). Statistical literacy at school: Growth and goals. Mahwah, New Jersey: Lawrence Erlbaum Associates.

Zhang, Q., \& Stephens, M. (2016). Profiling Teacher Capacity in Statistical Thinking of National Curriculum Reform: A Comparative Study between Australia and China. Eurasia Journal of Mathematics, Science \& Technology Education, 12, 733-746. 